\title{
ラットに及ほすす塩化シフェニールの影響
}

九州歯科大学料科薬物学教室（指導：吉村泰治教授）

黒木 賀代子・伊 藤 嘉子・村上雄 次

（昭和45年 3 月 20 日受理）

\section{THE TOXICANT EFFECT OF CHLORINATED DIPHENYL COMPOUND UPON RAT}

By

Kayoko KUROKI, Yoshiko ITOH, Yuji MURAKAMI

Department of Dental Pharmacology (Director : Prof. Taiji YOSHIMURA)

Kyushu Dental College, Kitakyushu, Japan

Because of the fact that chlorinated diphenyl compounds were originally developed as heat-exchanging medium for exclusive use in some processes of chemical industry, it is no wonder that there lacks any information with regard to its biological effect, much less with regard to human toxicity.

The present study was undertaken to examine the possible toxic effect of one of such compounds marketed under the name of Kanechlor when it was administered to rats orally for 10 to 20 days period in doses ranging from $2,500 \mathrm{ppm}$ to $10,000 \mathrm{ppm}$ in $0.5 \mathrm{ml}$ of solution per day.

The results were summarized as follows.

1. The drug did not cause any one case of death among the total of 102 animals tested.

2. The animals failed to gain weight and showed poor appearance of hair and dullness of mobility.

3. The sucklings from mother rats given to compound likewise showed similar morbid symptoms reflecting contamination of breast milk with the compound.

\section{緒訾}

有機塩素剤の一種である塩化ジフェニール（临品名力 ネクロール）は本来化学工業に打りる優れた熱媒体亡し て開発され，使用されてきた物質である。したがって， 熱媒体としての諸性質については検討されたが2，人体 に対する毒性についての関心は非常に薄かった。僅かな がら，塩化ジフェニ一ルを工業的に取扱う場合の労災基 準として，空気中に打りる許容量 O.5〜 I ppm という規 定がある。しかし，その場合も，実際に中毒を起すのは この数十倍ないし数百倍をあるうと推定されている.

われわれは，との物質が経口的に摄取された場合にい かなる毒性を現わすかを調べるため，ラットを用いて下 記のごとき実験を行なった。
成体ラットを用いた実験では，塩化ジフェニールを経 口投与した場合に現われる種々の作用の観察し性別によ る差異党検討した。仔ラットを用いた実験では，発育成 長に及将影響を調べた。また，授乳ラットを用いた夹 験では, 出産直後より塩化ジフェニールを経口投与した 母ラットの観察上平行してその母ラットの母乳だけを摂 取して成長している仔ラットに現われる影響を調へるこ とを目的とした：二，三の知見を得たので報告する。

1. 使用動物

$$
\text { 実験 方 法 }
$$

実験にはラット（Wistar-King）を用いた。

1）塩化ジフェニールを直接経口投与する実験には下記 
のあのを用いた。

(1)成体ラット（平均体重 232.5g, 生後 50 60日目の 此雄)

(2)仔ラット（平均体重22.5g, 生後14日目の雌雄)

2) 塩化ジフェニールを授乳ラットに経口投与して，そ の仔ラットへの影響を調べる実験には出産（第二回目） 直後の母.ラットで産仔数が 6 〜 13匹のものを選んで用い た.

\section{2. 動物の飼育}

実験に用いた動物はすべて約 $20^{\circ} \mathrm{C}$ の室温に抽いて固 型飼料（オリエンタル M F ） と水を自由に与えて飼育し た。

また，実験動物はこれらの条件下に少くとも一週間飼 育して全く異常の認められないあのだけを用いた。

ただし，仔ラットの場合は生後21日まで同腹仔と共に その母ラットの飼育箱にて母乳によって飼育し, 離乳後 は，固型餇料（オリエンタルMF）上水を与えた。

3。実験に供した薬物

塩化ジフェニール(阔品名カネクロール 4002$)$ ） は北 九州市小倉保健所より提供されたものを使用した。

\section{4. 薬物投与方法および用量}

塩化ジフェニール溶液の調製には, 溶媒としてゴマ油 （第七改正日本薬局方品）を用いて濃度を $2,500 \mathrm{ppm}$, 5,000 ppm, 10,000 ppmの3種とした。

投与方法は上記の如く調製した薬物をピペットを用い てロ腔内に注入し，自発的にえん下せしめた。注入した 時期は，摄食活動の著しくない午後 I 時より 4 時までに 行なった4).

薬物の用量および投与期間は次の通りである.

\begin{tabular}{|c|c|c|c|c|}
\hline & 動 物 群 & $\begin{array}{l}\text { 䆝化ジフェ } \\
二 \text { ールの濃度 }\end{array}$ & 用 量 & 投与期間 \\
\hline 奏験 I & 成体ラット & $10,000 \mathrm{ppm}$ & $\begin{array}{c}1 \text { 日 } 1 \text { 回 } \\
0.5 \mathrm{ml}\end{array}$ & 16日間 \\
\hline 実験 2 & 仔ラット & $\begin{array}{l}2,500 \mathrm{ppm} \\
5,000 \mathrm{ppm}\end{array}$ & 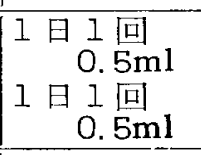 & $\begin{array}{l}\text { 10日間 } \\
\text { 10日間 }\end{array}$ \\
\hline 実験 3 & 授乳ラット & $10,000 \mathrm{ppm}$ & $\begin{array}{c}1 \text { 日 } 1 \text { 回 } \\
0.5 \mathrm{ml}\end{array}$ & 20日間 \\
\hline
\end{tabular}

\section{5. 使用動物数}

本実験に拈ける使用動物数は 102 匹であるがその内訳 は次の通りである。

1）成体ラットに対する経口投与実験では，雄 2 匹，雌 2 匹の計 4 匹を1群とした。

2）仔ラットに対する経口投与実験では母ラット A，
B，Cの仔ラットの中から雌雄各一匹ずつをとり合計 6 匹となしてれを一群とした。

3）授乳ラットに対する経口投与実験には出産直後の母 ラット6匹を用いて実験した。

また，上記 3)の実験に用いている母ラットの母乳を摄 取して成長している仔ラット屯害験観察の対象とした。

この実験の母ラットの産仔数は次の通りである.

\begin{tabular}{|c|c|c|c|c|}
\hline 対＼cjkstart照 & $\begin{array}{l}\text { 母ラット } \\
\text { 母ラット }\end{array}$ & $\begin{array}{l}\text { 産 仔 数 } \\
\text { 産 仔 数 }\end{array}$ & $\begin{array}{c}7 \\
13\end{array}$ & \\
\hline $\begin{array}{l}\text { 塩化ジフェニ } \\
\text { 投与群 }\end{array}$ & $\begin{array}{l}\text { 母ラット } \\
\text { 母ラット } \\
\text { 母ラット }\end{array}$ & $\begin{array}{l}\text { 産 仔 数 } \\
\text { 産 仔数 } \\
\text { 産仔数 }\end{array}$ & $\begin{array}{c}12 \\
9 \\
9\end{array}$ & $\begin{array}{l}\text { 匹 } \\
\text { 匹 } \\
\text { 匹 }\end{array}$ \\
\hline $\begin{array}{l}\text { ゴマ油 (単味) 投 } \\
\text { 与群 }\end{array}$ & 母ラットI & 産 仔 数 & 6 & 匹 \\
\hline
\end{tabular}

6. 観察事項

1 ）一般居動

動物の一般居動変化について投与後数時間の観察を毎 日反復した。 また，体重测定時および夜間における居動 観察も行ない合わせて検討した。

2 ) 体重

個々の動物について隔日的に体重測定を行ない，投与 開始日における体重との差，すなわち投与開始後の体重 変化量を求めた。 これより各投与群に招ける平均值を求 め比較に供した。

3 ) 眼所見

眼脂分泌, 眼瞼, 結膜および角膜の状態, 開眼の状態 を観察した。

4）皮膚所見

皮膚扰よび爪の変形, 変色, 皮疹の有無, 発毛, 毛の 状態を観察した。

5 ) 外性殖器所見

異常の有無, 発育程度を比較した。

6) 畨牙の発育, 歯肉の異状の有無をみた.

以上の観察事項のうち，3）～6）については，実体 顕微鏡を用いて，毎日観察した。 また，眼所見および口 腔所見については專門医に検晾を依頼した。

\section{実 験 成}

\section{1. 一般居動}

（実験 1）成体ラットに10,000 ppm塩化ジフェニール を投与した場合

投与開始後 $2 \sim 3$ 日目より運動性が鈍化した。この変 化は夜間に抢ける観察に抢いて特に著しかった。また外 
図 3 成体ラット（古）の体重変化

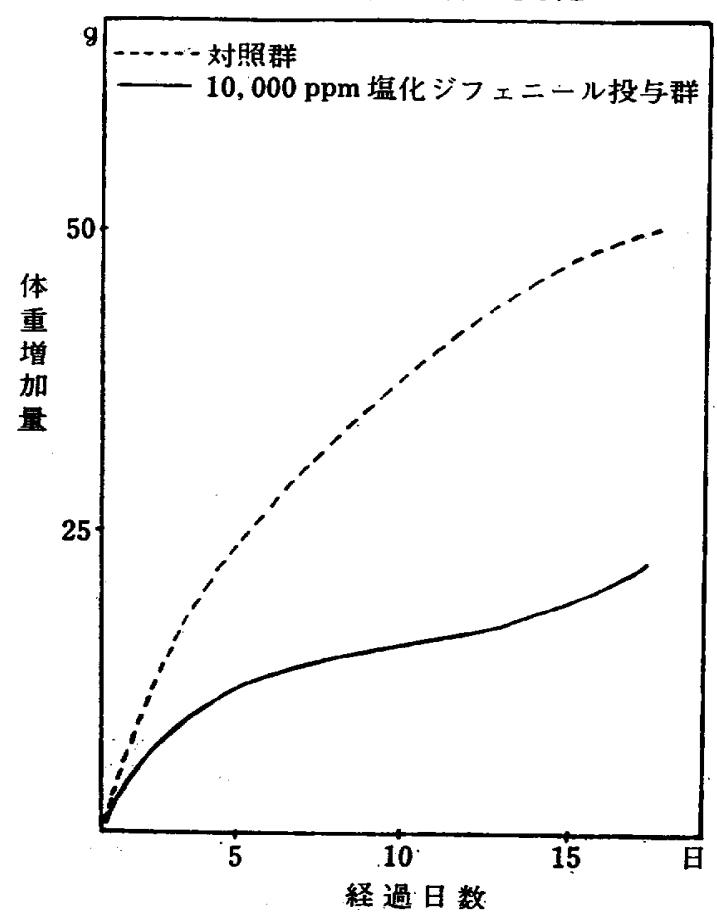

2，3）に示した．経過日数と共に投与群と対照群の体 重増加量の差は大きくなる傾向を示し, 投与-開始後16日 目には投与群は対照群の54.6\%となった。乙れを雌雄別 に見ると雄.ラットでは $62.2 \%$ 䧳ラットでは $42.3 \%$ \% る.

（実験 2）仔ラットに2,500 ppm および5, 000 ppm 塩 化ジフェニールを投与した場合

投与開始後の体重増加量は（表 2) および（図 4) に
図 4 仔ラットの体重変化

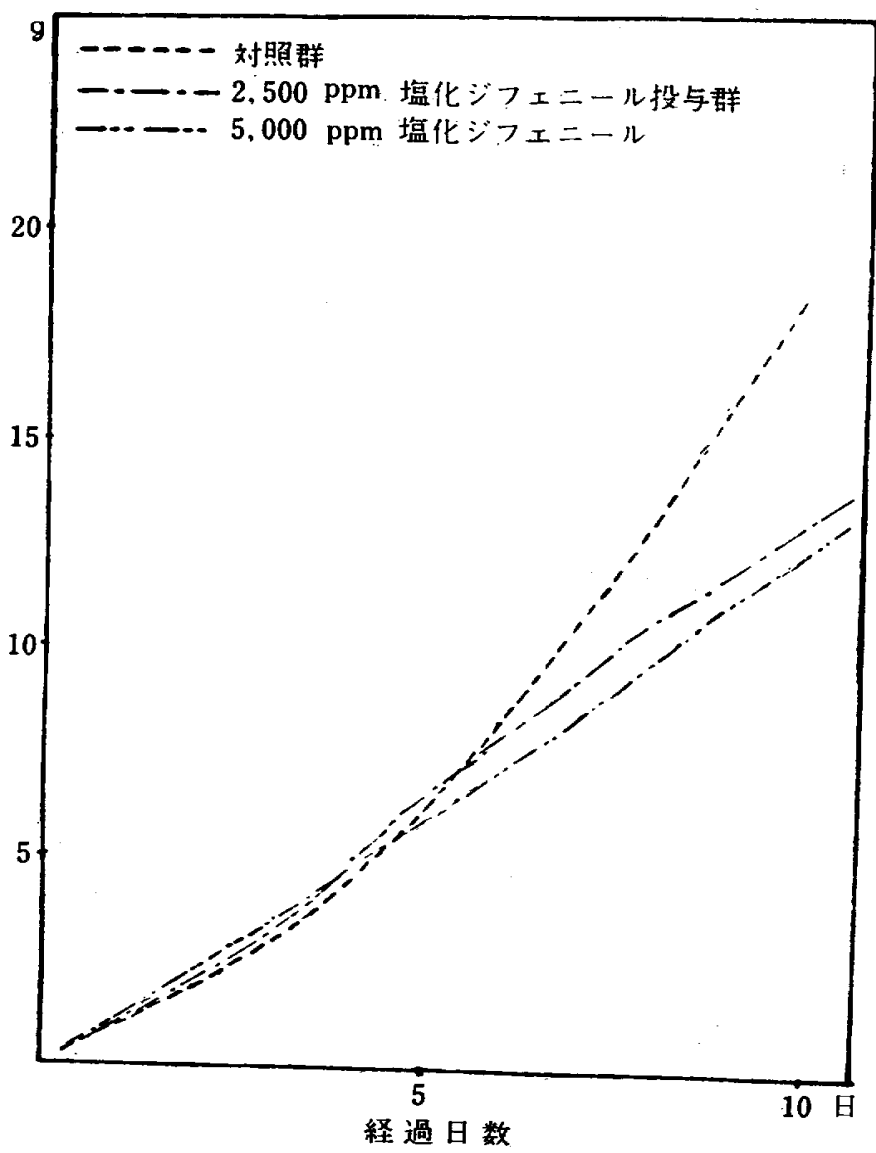

示した。塩化ジフェニール投与群では，6〜7日目より 影響が現われはじめた。投与開始後10日目の体重増加量 を刘照群に比較すると，2,500 ppm投与群では71.19\%， 5,000ppm投与群では68.0\%であった。

（表 2)

多ラットに 2,500 ppm 及び 5, $000 \mathrm{ppm}$ 塩化ジフェニールを投与した場合の体重増加量

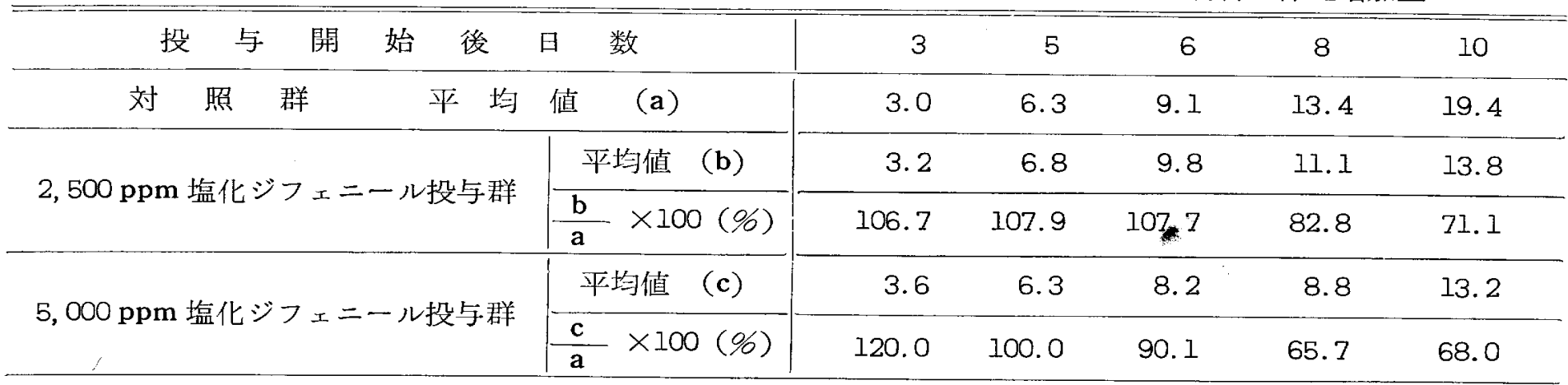

（表 3） 授乳ラットに 10,000 ppm 塩化ジフェニールを投与した場合の体重増加量

\begin{tabular}{|c|c|c|c|c|c|c|c|c|c|c|c|}
\hline & 経 & 過 & 数 & & 2 & 4 & 6 & 8 & 10 & 12 & 14 \\
\hline 対 照 & 群 & 平 & 值 & (a) & 1.3 & 4.8 & 8.5 & 13.3 & 19.5 & 19.5 & 19.7 \\
\hline 塩化ジフ & $x=$ & 一ル投上 & 群平均値 & (b) & 0 & 0.4 & 1.2 & 4.5 & 7.0 & 7.0 & 5.0 \\
\hline $\begin{array}{l}\mathbf{D} \\
\mathbf{a}\end{array}$ & $x$ & 100 & $(\%)$ & & 0 & 8.3 & 14.1 & 68.8 & 35.9 & 35.9 & 25.4 \\
\hline
\end{tabular}


図 5 授乳ラットの体重変化

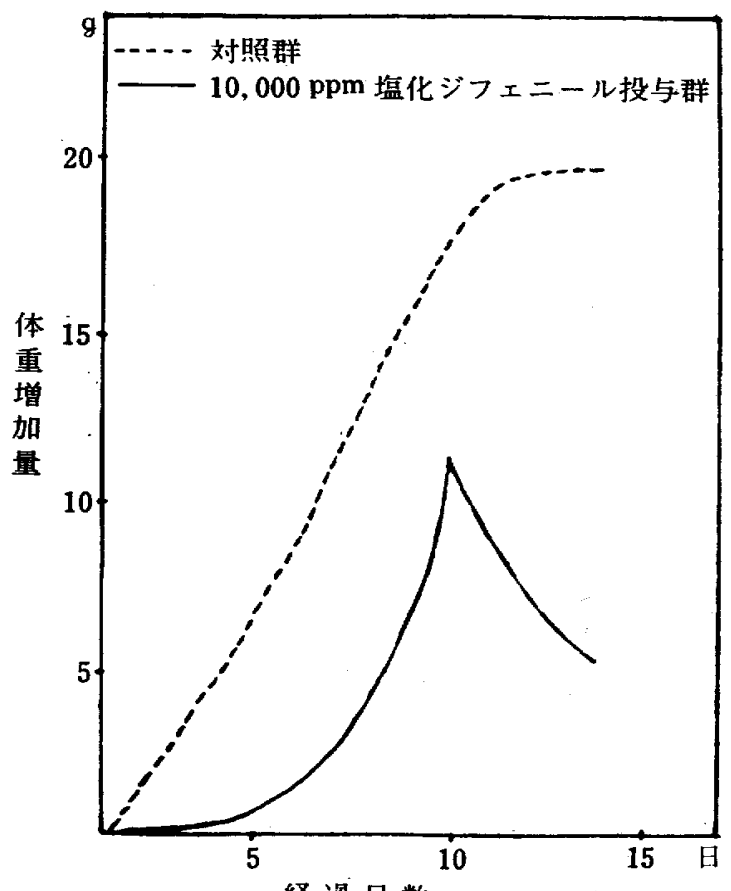

（実験 3 ）授乳ラットに10,000 ppm塩化ジフェニール およびゴマ油 (単味) を投与した場合

出産日より塩化ジフェニールを投与した母ラットの体 重増加量を（表３）拉よび（図５）に示した。投与群に おいては体重増加が少なく，投与開始後10日目からは体 重の減少がみられた。

また，塩化ジフェニールを投与した母ラットの母乳を 掑取している仔ラットに抢ける体重増加量を調べた結果 は，（表 4) および（図6）の如くである。投与群の仔 ラットは対照群の仔ラットに比べて体重増加が少なく， 出産日より離乳前日の20日目に扔いて前者は後者の63.6 \%となっている。外見的にも投与群の仔ラットは明らか に体格が劣っている。

なお，ゴマ油を投与した授乳ラット抢よびその母乳で 成長した质ラットの体重増加は対照群よりもわずかに良 好であった。

\section{3 . 眼所見}

（実験 I），(実験 2），(実験 3）のいずれにおいてす （表 4) 10, 000 ppm 塩化ジフェニールを投与したラットの母乳で充つ仔ラットの体重増加量

\begin{tabular}{|c|c|c|c|c|c|c|c|c|c|c|c|c|c|c|}
\hline & 経 & 過 & 日 & 数 & 2 & 4 & 6 & 8 & 10 & 12 & 14 & 16 & 13 & 20 \\
\hline 対 照 & 群 & 平 & 均 & 值 (a) & 0.8 & 3. 1 & 6.0 & 9.0 & 12.7 & 16.3 & 19.5 & 22.5 & 24.9 & 30.8 \\
\hline 塩化ジ & $I=$ & ル ル & 群 & 平均值 (b) & 0.5 & 2.1 & 4. 2 & 6.5 & 8.8 & 11.1 & 13.2 & 15.2 & 17.1. & 1.9 .6 \\
\hline$\frac{b}{a}$ & $\times$ & .00 & & $(\%)$ & 62.5 & 67.7 & 70.0 & 72.2 & 69.3 & 68.1 & 67.7 & 67.6 & 68.7 & 63.6 \\
\hline
\end{tabular}

図6 授乳ラットに塩化ジフェニールを投与した場合 の存ラットの体重変化

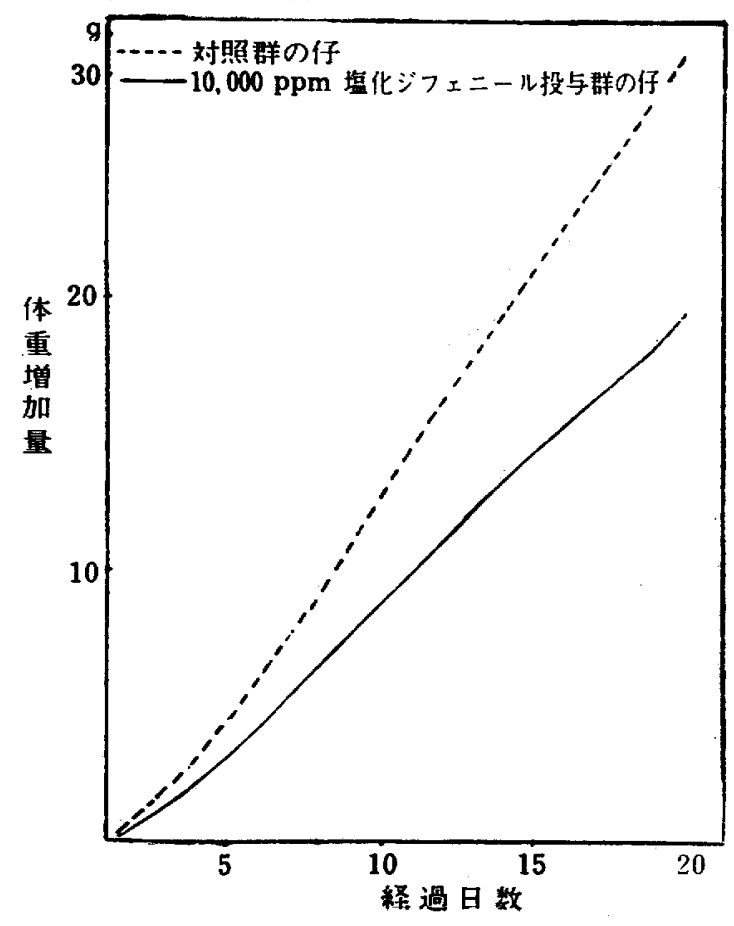

眼脂分泌, 眼臉, 結膜および角膜の異状は認められなか った。

4. 皮度所見

（実験 1 ）成体ラットに10,000 ppm塩化ジフェニール を㸭与した場合

投与開始後，2〜3日間を経過すると立毛が目立ち， 毛の光沢がなくなった。 その他の変化は認められなかっ た。

（実験 2 ）仔ラットに2, $500 \mathrm{ppm}$ および 5,000 ppm塩 化ジフェニールを投与した場合

2, 500 ppm 投与群掞よび5, 000 ppm 投与群のいずれに おいても同程度の立毛が起り, 体毛の光沢が失われ, 黄 色味を带びてきた。

（実験 3 ）授乳ラットに10,000 ppm塩化ジフェニール およびゴマ油を投与した場合

塩化ジフェニール投与群掞よびゴマ油投与群のいずれ においてあ皮膚所見に関し母ラットには变化が認められ なかった。 
塩化ジフェニール投与群の仔ラットは発毛の状態が悪 く，特にその影響は腹部の発毛に対して強く現われた。 また，耳殼周辺には太く短い毛がまばらに生えた。

ゴマ油投与群の仔ラットに打いては皮膚所見に関し， 異状は認められなかった。

以上のごとく（実験 1 )，(実験 2 ），(実験 3 ）におい て体毛に対する塩化ジフェニールの影響は明らかに認め られたが，その他の屓鹰所見に变化は認められなかっ た。

\section{5. 外性殖器所見}

成体ラットおよび授乳ラットにおける外性殖器の異状 は認められなかった。

仔ラットの外性殖器の発育状態も対照群にほぼ一致し て扣り，異状は認められなかった。

\section{6. 口腔所見}

成体ラット，授乳ラットおよび仔ラットにおいて歯牙 の着色, 歯肉扔よび口腔粘膜の異状は認められなかっ た。 また，仔ラットの雬牙発育に関しても変化は認めら れなかった。

7. 致死効果

$2,500 \mathrm{ppm}, 5,000 \mathrm{ppm}, 10,000 \mathrm{ppm}$ 塩化ジフェニル投与群抢よびゴマ油投与群のいずれにおいて屯致死例 をみなかった。

\section{考察}

有機塩素剂の一種である塩化ジフェニール（商品名カ ネクロール）は食品化学工業において熱媒体として使用 されているが，この物質を急性中毒を起さしぬない用量 で一定期間経口投与した場合，その毒性を調べるこ之 が本実験の目的であった。 そのため 2, $500 \mathrm{ppm} ， 5,000$ ppm，および 10,000 ppm 塩化ジフェニール溶液の 0.5 $\mathrm{ml} / \mathrm{day}$ を10ないし20日間ラットに経口投与して実験を 行なった。この量を換算すると，成体ラットには約 25 $\mathrm{mg} / \mathrm{kg}$ ，仔ラットには 25 $125 \mathrm{mg} / \mathrm{kg}$ ，授乳ラットには 約 $20 \mathrm{mg} / \mathrm{kg}$ ，を1日量として投与したことになる。

これらの用量を10ないし20日 間毎日経口投与した結 果，全く致死例をみなかった。したがって，てれは種々 の中毒症状の観察を行なうには好都合な条件であった之 言える.

各実験を通じて，一般居動，体重，眼所見，皮膚所 見, 外性殖器所見, 口腔所見の六項目をみた。

まず，塩化ジフェニールをラットに直接経口投与した 結果について考えるに，一般居動の観察では，成体ラッ トにおいては，投与開始後 2 ないし 3 日目より運動性の
低下がみられた。これは特に夜間の活動期においては物 に著しかった．しかし，仔ラットおよび授乳ラットにお いては，ほとんど変化は認めら杖なった。

体重の変化については，(実験 I)，(実験 2 )，（実馴 3）に㧍いて，投与開始日における体重亡，投与開始行 の体重との差を体重変化量として対照群と比較した。 の結果, 成体ラット，仔ラット，授乳ラットのいずれの 場合に㧊いても，明らかに体重増加が抑制されたてと力 わかった。

各実験ごとに体重変化量については，対照群に対する 薬物投与群の割合を求めていたが，その値を一括して， ラフに表わしたものが（図７）である，図中，体重変 率とは，対照群の体重変化量を 100 とした時の各実験君 の体重変化量である。したがっててのグラフにより，妍 物投与に上る体重増加抑制の程度を各実験群の間で比輬 することができる，成体ラット，仔ラットおよび授乳 ットのうち，投与開始後直ちに強い影響の現われてい のは出産直後の授乳ラットであった。これに比べて仔 ットでは，投与開始後4ないし6日目まで体重変化に目 して影響は全く現われなかった。投与開始後10日間の仡 重変化を比較すると, どの実験群も体重増加は対照群。 約70\%にまで抑制されている。しかし雌ラットの場合。

図7ラットに直接経口投与した場合の塩化ジフェニ 一ル投与群の体重変化

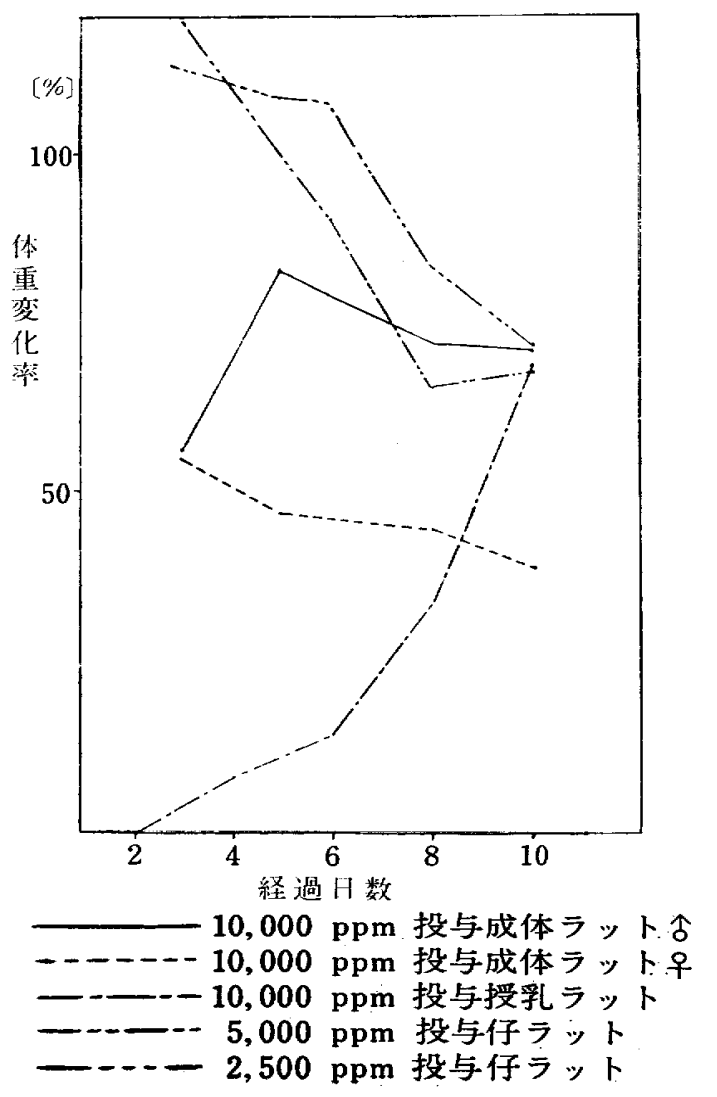


みは約40\%となって扔り，より強く影響を受けていると 考えられる.

皮膚所見については，実体顕徽鏡を用いて皮湍の变 色, 皮疹の有無, 爪の変形打よび変色, 体毛の変化につ いて観察を行なった。体毛の変化は，成体ラット执よ゙ 仔ラットに現われ，まず立毛が起り，体毛のつやが失わ れ，黄色を帯びてきた。 この変化は投与開始後 2 ないし 3日目より明らかとなった。 その他の観察内容について は変化はみられなかった。

眼所見, 外性殖器所見, 口腔所見に関しては，いずれ の実験においても変化注認められなかった。

以上のごとく2,500 ppm ないし 10,000 ppm の塩化ジ フェニールを経口投与した場合に明らかに認められた影 響は，(1)運動性の低下 (2)体重増加の抑制 (3)体毛の変 化であった.

また，授乳中の母ラットに塩化ジフェニールを投与し た実験においてはその母乳を搷取している仔ラットにつ いても同様の観察を行なったが, 結果は次のとおりであ った。

一般居動, 眼所見, 外性殖器所見, 口空所見に関して は異状を認めなかった。しかし体重増加の抑制は，直接 経口投与した仔ラットの場 合と同程 度に現われた。 ま た，対照群の授乳ラットの仔に比べて発毛が遅れ，体格 あ劣り, 発育状態が悪かった。

この差の原因として, 授乳している母ラットの個体差 や産仔数の差も挙げられると思うが，乙の実験結果よ り, 消化器官より吸収された塩化ジフェニールが母乳中 に分泌されてくることが疑われる。乙れを確かめるため には母乳中の监化ジフェニールを化学的に証明する必要 があると考える。

\section{結論}

有機塩素剂塩化ジフェニールをラットに経口投与して その影響を検討した結果, 次のような結論を得た。

2,500 ppm，5,000 ppmおよび10,000 ppm 塩化ジフェ ニールの0.5ml/dayを10ないし20日間ラットに経口投与 した場合,

1. 実験に供したラット102 匹中致死例はみられなかっ た。

2.ラットの体重増加が抑制され，体毛の異状，運動性 の鈍化がみられた。

3. 眼所見, 外性殖器所見, 口腔所見においては異状を 認めなかった。

（本稿を終るにあたり，終始御懇篤なる御指導を賜わっ た歯科楽物学教室吉村泰治教授, 口腔病理学教室および 病理学教室の諸先生, また臨床的見地より御助言を賜わ った第一口腔外科学教室平川正輝教授, 外科学教室犬塚 貞光教授, 眼科専門医猪野新一郎先生に深謝の意を表わ します.)

\section{文献}

1. 桶口謙太郎; 新皮膚学科学, 南山堂 (東京), (1968).

2. 鐘㴊化学工業株式会社研究所; 不燃性熱媒体力方ク ロール，鐘㴊化等工業 (大阪)，(1965).

3. 食糧㕂; 植物油㴯製造設備機械に関する資料, (1961).

4. 田辺堅三郎, 高折修二, 島本暉朗 ; 5-n-Butyl-1cyclo-hexyl-2, 4, 6-trioxoperhydropyrimidine

（B C P）の毒性；日本楽理学雑誌，63，105一 122, (1967).

5. 小山良修; 動物実験手技, 215一-236, 共同医書（東 宗), (1958). 